\title{
Access or Set Up? A Critical Race Feminist, Black Consciousness, and African Feminist Perspective on Foundation Studies in South Africa
}

\section{Corinne Knowles}

\begin{abstract}
Foundation provision for South African university students has been a national programme to redress the inequalities of apartheid. This paper considers the ongoing concerns around race, gender and class inequalities, raised, for instance, during the 2015, 2016 student protests in South Africa. Three theories are used as a lens to consider foundation programmes in this context: Critical Race Feminism, Black Consciousness, and African feminism. Critical race feminism is not a new theory - for example bell hooks' work on feminism and liberatory pedagogy, and Krenshaw's work on intersectionality, date back several decades, but remain relevant. Black consciousness, popularised by Steve Biko in the 1960's and 70's, continues to inspire a thoughtful consideration of race in South African society. African feminism argues for noticing the silenced voices and finding the communities that animate their knowledge seeking. Some of the complications in the success of the foundation studies, and in transformation of universities, can be better understood by using these lenses to interrogate race and class dynamics on campuses that continue to struggle to transform. The paper reminds us of the university's purpose as a public good, and asks us to locate the poor, black student in the centre of our deliberations.
\end{abstract}

Keywords: Foundation studies, public good, African feminism, Higher education transformation, inequality 


\section{Corinne Knowles}

\section{Introduction and Context}

Universities in post-apartheid South Africa have undergone numerous transformations since the onset of democracy in 1994, driven by new constitutional imperatives of a better life for all. Some of us who teach in national universities feel a profound responsibility to help to undo the legacies of colonialism and apartheid, so that our students' experiences and learning can be relevant to their participation in a more progressive and equitable future. While universities have undergone all sorts of changes since the move to democracy in 1994 (for example, Reddy 2004), nationwide campus protests in 2015 and 2016 raised students' concerns around the rate and content of our transformation efforts. The hash-tagged protests at various universities (\#RhodesMustFall; \#RhodesSoWhite; \#Luister; \#FeesMustFall; \#RUReferenceList) exposed some of the ways in which race, class and gender inequalities continue to divide society, and be under-recognised and unresolved in South African universities (for example, Muzenda 2018; Chengeta 2018). Most of the protesting students across the country were black $^{1}$, and they were passionate about the need to rethink the purpose of the university and the place of the black young person in it. This paper proposes three theories that could orientate our thinking to address these concerns, including how we think about foundation studies. At the university where I teach in a foundation programme, many of my ex-students were part of the 2015 and 2016 protests. They were fighting to be recognised, to be valued, to be central rather than marginal, in the university that had invited them to be part of its programme.

The nationally devised foundation studies programmes were set up as part of the transformation of the higher education system (White Paper 2013). Their aim has been to increase access in the South African post-apartheid university landscape, by providing different kinds of support to 'underprepared' students (Boughey 2010; Badat 2011; CHE report 2013). However, the CHE report of 2013 estimates that 55\% of those who enter university will never complete their degrees (2013: 14), which suggests that many students who are accepted into the university system are underprepared, or that the university itself is underprepared for the students it accepts. In a South African university context of high dropout rates, poor throughput,

\footnotetext{
1 'black' is used in the political sense encompassing those who were classified as 'non-white' in the apartheid regime (see Mahlangu 2012).
} 
economic and social strain (World Bank Report 2018), and success rates that continue to be raced and classed (Pather 2018), we are urged to question the theories and pedagogies that shape academic interventions such as foundation programmes. These programmes tend to attract students who have completed township or rural schooling, and who qualify for the National Student Financial Aid Scheme (NSFAS). In other words, foundation programmes are most likely to attract the poor, black young person, who might or might not obtain a degree. The programmes have perhaps been successful in addressing the articulation gap between school and university (CHE Report 2013: 71,72), but this paper suggests different ways to think about 'success', and wonders about the articulation gap between the foundation programme and the rest of the degree. If the programmes, or indeed the pedagogies that we use in universities in South Africa, perpetuate the profound race and class inequalities in our society, we are failing the young people who enter university to lift themselves and their families out of poverty and inequality. We are also failing the public. It seems that the focus of our institutions is narrowing from one that includes the majority poor as the public, to one that relies on the success and benefit of a few individuals. Mkhize argues that universities in their current form have very little return on investment, and instead 'churn out a 'multiracial' middle class that can fit into a very narrow professional stratum' (Mkhize 2015). The theories that I explore in this paper ask us to reconfigure how we conceptualise 'success' in our transformation and pedagogic strategies, to include how capable and equipped graduates are to contribute to the national transformation project to reduce class and race inequalities. This has implications for how we think about foundational provision, which prepares and supports students for successful participation in mainstream disciplines.

At the university where I teach, the foundation programme is a firstyear augmenting course ${ }^{2}$ which consists of a smaller class, which facilitates a different kind of teaching and learning supported by the theories and ideas I explore in this paper. My class is usually between 35 and 40 students, who take Politics 1 and Sociology 1 with mainstream students, and then participate in

${ }^{2}$ While foundation provision is a national strategy in South African universities (White paper 2013; CHE report 2013), it is largely up to the individual university to practice their own interpretations of this. I acknowledge that my experience is not necessarily mirrored in how this is experienced in other universities. 


\section{Corinne Knowles}

augmenting classes for these subjects with me. Because of the small size of the class, and because my teaching is aligned to hooks' and Freire's humanising, participatory, liberatory pedagogy (hooks 1994; Freire 1970), we get to know each other well during their foundation programme year and remain in informal contact throughout their degrees. In the foundation/ augmenting year, we unpack concepts explored during their mainstream courses, finding examples from current South Africa and the continent, and seeking the relevance for South African society (Knowles 2014). The kinds of work we do and the way we do it - where the student is central and recognised - is not necessarily followed through in their mainstream university disciplines. Part of my dilemma and the reason for writing this paper rests with the question about whether my way of teaching sets students up for failure, once they leave my class and continue their degree in an unforgiving mainstream that is neither Afrocentric nor student centred. It has led me to ponder on the purpose of the university, and how to teach with ethical integrity not only in foundation courses, but also in mainstream disciplines. The implication is that the theories help us to conceptualise more relevant pedagogy and planning for all sectors of the university, so that foundation studies do not become a kind of ghetto where 'disadvantaged' students are 'fixed' to enable their 'success' in the mainstream.

If our universities are institutions of public good (Badat \& Singh 2001; Mama 2003) what is the 'good' and who is the 'public' that they serve? According to a recent World Bank report (2018), South Africa is one of the most unequal countries in the world, and 'inequality is high, persistent, and has increased since 1994'. Sayed argued a decade ago that despite the lack of clarity about what it means, 'the reduction and elimination of poverty is becoming a key component of education policy' across the board, and prominent in 'government efforts at national development' (Sayed 2008: 53). What contribution has the university made in the last decade in the form of graduates who will enter the market and provide leadership and clarity regarding the reduction of poverty? What can we predict for the next decade? This paper doesn't necessarily answer these questions but directs our thinking to theories that will help us to grapple with them.

In this paper, I argue that the increasing inequalities in our country and universities encourage a critique of the pedagogies that we currently facilitate and reward in universities and the foundation programmes we devise. If in post-apartheid South Africa, inequalities have become increasingly 
exacerbated, we are not getting it. We are perhaps looking for answers in the wrong places or not seeing the whole picture. Universities could and should equip students with the recognition, confidence and resilience to complete their degrees and make important contributions to society. This paper looks for different approaches that might re-orientate our thinking of the foundation programme as a project for the public good, to include the majority who are poor and black.

The theories that can re-orientate our pedagogies, interventions and practices in universities, can re-centre those who are currently least successful in universities and societies. This will disrupt the neoliberal tendencies in our thinking, because the subject of our thinking shifts to align with those who are least advantaged. Critical Race Feminism, Black Consciousness, and African feminism overlap to help us understand the challenges and opportunities in the foundation programme in South African universities. Each of them has a unique contribution to make. The theories and appropriate methodology will be discussed for their relevance to the sector, and two themes will clarify their usefulness: the reconnection of mind, body and spirit; the public and the good.

\section{Introduction to the Theories}

One purpose of theory is to guide our thinking when we make policies, programmes and decisions about funding and pedagogy, for instance about foundation programmes and higher education, and how we view 'success' in this context. But theory is not arbitrarily an intellectual frame to understand and address the social problems of our worlds - it is also a contextual and political choice. How we choose to think is based in part on the kinds of exposure we have had to which theories; and the resonances we experience with thinkers that address the challenges that concern us (Few 2007: 467). Our choice is also guided by how we understand power, which values we esteem, and to what ends we are focussing on an issue or phenomenon. I am drawn to seek out the thinkers on this continent, and who also resist imperialism and colonialism, to find the resonances that orient the thinking about foundation programmes towards social and epistemic inclusion and justice. It is poor black young people who are most vulnerable in our universities and society - as I will argue in more detail, our theories can move beyond a 'talking about' to a 
'talking with', and be relevant and even transformative in application, if they are resonant with those they research.

Students enter our universities, many of them with dreams to move beyond poverty into firm employment. But South Africa struggles with chronic unemployment, especially in the youth category (Skade 2016; Linden 2017; Statista 2018). There are arguably more sustained benefits to a university education than for individual benefit only. Thinking of the university as a public good, and locating our thinking in Africa, can expose a different set of benefits. Ngugi (1986: 1139) argues compellingly that

Education is a means of knowledge about ourselves... After we have examined ourselves, we radiate outwards and discover peoples and worlds around us. With Africa at the centre of things, not existing as an appendix or a satellite of other countries and literatures, things must be seen from the African perspective.

When we locate our thinking about foundation studies in and of Africa, and push back against colonialism and inequality, we find that a particular set of experiences and perspectives is revealed that shift our thinking about the why, what and how of the foundation programme. As Sayed argues, in a discussion that looks at the link between education and poverty reduction: one's questions and answers, 'to an extent, depend on who is asking them and what the understanding of poverty elimination is' (Sayed 2008: 54). Theory shapes how we see the world and will frame our data, and what it can tell us, when we are making or using a theory. The theories we use help us to think through the foundation programme and analyse the problems and prospects that we see, anticipate and facilitate.

Although Appiah has been critiqued for anti-Afrocentrism, arguing instead for 'cosmopolitanism' (2006) that transcends the hierarchies of social structures, he agrees that theory is political, in that it will always find the data to support it. Arguing against an essentialist Positivism, he asserts that theory 'never came free of theoretical commitments' (Appiah 2006:40). Appiah borrows Burton's image of a shattered mirror, to remind us that 'each shard...reflects one part of a complex truth from its own particular angle' (2006:8). To recognise that any theory (that will find evidence to support it) is entangled in the intentions and politics of those who use or make it, implies that we should also be curious about where the theorist is standing, in what 
context - which shard of mirror is she holding and whose world does it reflect? ${ }^{3}$ My work for the last decade has been in foundation studies, and my pedagogic praxis is deeply influenced by and reflects those who are least advantaged in the university. Theory that is being remade through an ongoing conversation between ideas and the narratives of those researched, can help us to find a way towards more inclusive coherence in this sector. Critical race feminism, Black Consciousness, and their synergies with African feminism, are all standpoint theories which have helped me to relocate the poor black student at the centre of our deliberations about foundation programmes in South Africa.

Critical race feminism emerged in the legal field where researchers claimed that the critical issues of race needed to be complicated and enhanced by adding the layers of gender and class to understand the sometimes-triple nature of oppression (Childers-McKee \& Hytten 2015; Carter 2012). The intersection of these identity markers, and how they shape and are shaped by the legal and policy frameworks in our social life, are pertinent to our thinking on foundation programmes in South Africa. Students who enter foundation studies, in my experience, are black, and many of them are poor. The intersection of race and class have significant influence on how they experience a formerly white, and arguably middle-class orientated university. The theory argues that not only is it important and necessary to understand the social structures that contribute to inequality and oppression in overlapping ways, but that we need to understand this oppression from the perspective of the oppressed. It argues strongly for the centrality of the oppressed, using unconventional research methods that disrupt the single story of essentialist notions, by featuring stories, poetry, fiction, and other non-traditional data to understand the multiple, overlapping identities that people bring to the research process (Few 2007:257).

Black Consciousness is another theory that re-centres blackness in how we can think about foundation programmes. In the USA, Black Consciousness was a way for African Americans to build a narrative that was not merely in response to dominant and oppressive whiteness, but that reestablished blackness as central (Jones 2002: xiii). In South Africa, Black Consciousness became the impetus for the student movement in the 1970's,

${ }^{3}$ As a white South African who works in this sector, I am assured and cautioned by Few's observation that 'how the standpoint is articulated matters more than the color of the researcher' (Few 2007:460). 


\section{Corinne Knowles}

because it reasserted the values and culture of black people that were denied their humanity by white people and the apartheid regime (Biko 1978). More recently, Daniels argued during the sometimes violent 2015 student protests, that 'righteous anger is not arbitrary. It is, in fact, sparked by an intellectual engagement with the brilliant black consciousness writers of the past and present, and it is the driving force behind organising for transformation' (Daniels 2015). Black Consciousness as a theory became a praxis during these protests, as students reclaimed recognition and agency in their demands for curricular and cultural transformation (Erskog 2015).

African feminism locates the struggles against colonialism and oppression firmly in community, using expanded epistemologies. Pushing against the individualism of western feminism, African feminism approaches social justice and human rights in a 'delicate balancing act... between personal needs and broader family or community needs' (Motlafi 2015). OlokaOnyango and Tamale warn us against the representations of western feminism, arguing that it is disconnected from the continental struggles against colonialism (1995: 692), and the ongoing effects of apartheid. African feminism calls for using the African woman as a lens, which will reveal things like the importance of spirituality as a 'political tool' so that we can 'be whole and fight the injustices, positioning the academic as one who fuses within this knowledge the head with the heart to understand the world' (Motsemme 2017). In a conversation with Elaine Salo, Amina Mama argues for an African feminist presence in universities because 'these are arenas that we must imbue with our own concerns, transform into places that serve our collective interests, instead of leaving them to continue perpetrating intellectual and epistemic violence against us' (Mama 2001:60).

These are strong ideas, and not new. Critical race feminism, Black Consciousness and African feminism are relevant to our thinking about foundation programmes, because they represent a shift in the kinds of exclusionary ways that decisions have been made about the programme up until now. They argue for the re-centring of the poor black student in our thinking and planning, to see her as a whole person, in community, rather than a generic object of our deliberations, so that we can use pedagogies that translate into an expanded notion of what 'success' is. All the theories emphasize the centrality of the narratives of marginalised groups, and the interplay between these and the social, political, and economic social structures that impact on students and staff on the programme. Locating marginalised 
groups as central in our thinking reminds us that our students are successful when they can think beyond their own individual benefit, to include a sense of belonging in a community that requires their expertise to overcome the challenges of poverty and racial oppression. Critical race feminism speaks of 'the importance of narratives, storytelling, and counternarratives to disrupting taken-for-granted and normative views about the world' (Childers-McKee \& Hytten 2015:395). Critical race feminism, Black Consciousness, and African feminism ask that the theory itself becomes porous, dynamic, in a praxis (Carter 2012: 4; Few 2007: 257-259) that is shaped by re-centring the object to become a subject in the constant generation of the theory. In this way, research participants become co-researchers (Mkabela 2005; Ntseane 2011).

While the theories have been briefly introduced here to clarify their main views and methods, they will be expanded in the discussion that flows through two key ideas which are related to each other, and to how we think about success: the reconnection of mind, body and spirit; and the university as a public good. In a society that is groaning under the weight and oppression of global capitalism, universities have taken on an increasingly neo-liberal tone that regards students as customers; that has a top-down approach to massification and its consequences for teaching and learning; and that disconnects students from their social and political realities to emphasize their economic value or burden (for example, Muller 2018). In this way, students entering a foundation programme are set up: they anticipate a life-changing opportunity, and instead become invisible in the way universities operate. The alienation that arises from this, profoundly affects the mental, psychological and physical health and wellbeing of staff and students and shapes the contributions we could be making to society. In this context, vulnerability and resilience are unequally experienced, in that the university tends to have a generic approach to students (and staff) and their emotional and social wellbeing, and intellectual expectations. As a result, those who fall outside of the parameters of who is recognised as a student, and what counts as a 'good' student, are made increasingly vulnerable, disconnected from themselves and their dreams, as those with power decide on their behalf what interventions, if any, are appropriate. This mirrors the unequal relations in society. As was experienced in the 2015 and 2016 student protests in South Africa, those who try to fight the slowness of transformation in the university system could feel the full might of state apparatus to silence them through violence, arrest or exclusion (see for instance Sesant et al. 2015). Linked to the reconnection of 


\section{Corinne Knowles}

mind to bodies that are socially structured, is the re-assertion of the university as a public good, using the theories to clarify what is good and who the publics are in South African society in this context.

\section{Mind, Body and Spirit: Reconnecting for the Public Good}

Part of the struggle in universities globally, and increasingly in South Africa, is the influence of neoliberalism on how we think about and treat students. Baatjies (2005) passionately critiqued this trend more than a decade ago, arguing that the introduction of the norms of 'efficiency and effectiveness' in political discourse at the time would corporatize the university, making the economics of institutions more important than the social contributions of intellectual work. The problems associated with the neoliberal trend are widespread, and profoundly affect the kind of education and experience available to students. Massification, the demand for better throughput, outsourcing teaching as contract posts, and regarding students as consumers, all contribute to a pedagogy that must be rationalised to separate the mind from the body.

When we do this separation, consciously or unconsciously, we erase the experiences, wisdoms and ways of knowing that our students bring, in their bodies and minds, to the university; and we also limit what we know of students to a mind that is generic, individual, and separated from social, material and spiritual context. When a lecturer faces a class of 600 or more students, it is rare and difficult to engage students in the making of knowledge, and in getting to know who the students are. As has been my experience in teaching a Sociology 1 course, an introduction to African feminisms, it is not an impossible task, but it takes a lecturer's commitment and orientation, with regular opportunities for student feedback, to inspire students to co-produce knowledge that is relevant for society. As Muller observes, this becomes difficult when financial incentives for staff are linked to student success, and in some cases, where there is 'the introduction of student throughput rates in academics' performance contracts, attempting to use formal punitive measures to force academics to pass students, regardless of their calibre and performance' (Muller 2018). I argue that throughput does not translate into success if students are not recognised and enabled to make the necessary contributions to the transformation of our unequal society. 
Neo-liberalism sets up particular kinds of performances. There is a decrease in curiosity; a reluctance to push students (or staff) to discuss and think through their own prejudices; a paucity of complicated and layered discussions around inequalities in society or in lecture rooms. Instead, students are categorised generically and survive or not according narrow assumptions and a separation of mind from body. The danger is that this western inspired Cartesian dualism creates 'a false division between mind and body in experiential learning that obscures our physical internalization of social realities' (Nguyen \& Larson 2015: 335).

Student protests at South African universities in 2015 and 2016 highlighted the need for relevant pedagogy, and a curriculum that was responsive to the experiences and challenges of students. Many protesters were poor black students. As Mkhize (2015) wrote at the time,

The students were talking about pedagogy, freedom, methodology and they were not doing it for 100 marks; they were articulating an intellectual vision for a more humane society and critiquing our universities for paying lip service to transformation.

In effect, students were asking to have their bodies and experiences recognised in the kinds of intellectual work they are exposed to in universities. This orientation would compel a different idea of what 'success' means in universities: it would expand the gaze of our pedagogies to include their relevance to the kinds of contributions that graduates can make to the undoing and transformation of race and class inequalities in South African society. The protests were, on the whole, a missed opportunity for university leaders, lecturers, and students to negotiate together the necessary shifts in the pedagogies, theories and thinkers that shape our work in universities.

Theories that emphasise dialogue and narrative methodology ask for a reconnection of mind, body and spirit that resists neo-liberalisation. Hooks speaks of the need to have a flexible agenda, responsive to who students are and what they bring to an encounter (hooks 1994:7). She argues that students need to be understood in 'their particularity as individuals' rather than as generic. The only way to do this, is for the lecturer to genuinely value the contributions of students, and to create a learning community. When students are not only recognised for their minds, but for their bodies and unique experiences, lectures become dynamic spaces of excitement through collective 


\section{Corinne Knowles}

effort (hooks 1994: 8). Berry (2010: 25) argues that Critical Race Feminism helps us to understand the 'the multiplicative and multi-dimensionality of being and praxis' of marginalised groups, for instance such as foundation programme students. We do this through letting students speak for themselves, in lecture room debates, discussions and reflections; and in research that challenges our assumptions and makes and uses theories that are relevant to our shared worlds. Hooks argues that this has implications for how we teach she argues that when 'education is the practice of freedom' (1994: 21), for instance from poverty and the legacies of apartheid, students are encouraged to express themselves, and to connect 'the will to know with the will to become' (hooks 1994: 19), or the mind to the body. Lecturers too, she claims, must be willing to grow in this process, and 'must practice being vulnerable in the classroom, being wholly present in mind, body and spirit' (hooks 1994: 21). The implications of this would be that how we think about foundation programmes, and pedagogy, and universities, and students, must be influenced by giving voice to students, and by an awareness that our institutions are shaped by social structures that have silencing effects on the most vulnerable in our universities. When the vulnerable and silenced voices in our society, our universities, and our foundation programmes, are enabled to speak for themselves, they can shape the content and purpose of our pedagogies.

If our institutional cultures continue to mirror a neoliberal economy and state, and if our theories are not making the marginal more visible, we miss out on an opportunity to provide hope, for individuals and the public, that a more socially just and humane society is possible. Poor black students have spoken about the alienation they feel in formerly white universities. For instance, Centwa (2013), a so-called poor black student from the local township at a formerly white institution, writes that 'the pressure is on for me to pretend to be who I am not'. Ellis warns of 'artificially formed determinants of Black identity created by the images of the twenty-first century' (Ellis 2002: 65). Applying a Black Consciousness lens to young black males in American society and universities, Ellis advises that in a context where racist, negative assumptions are made about young black males, it is up to them to find and articulate their own identities, their own academic directions, their own supportive networks, and to 'prepare themselves for success' in their academic journeys so that they might contribute to society and their communities (Ellis 2002:70). But how do, as an example, foundation programme students (or academics who write about them) think about and do this finding and 
articulating of identities, as Ellis suggests? Moodley, using Black Consciousness to think about South African society, argues that 'apartheid society also produced self-hate' (Moodley 1991: 238), because the 'limited range of opportunities' led black people to believe that they were to blame for their predicament, but also that the status quo was right. These ideas are decades old. And yet, in a neoliberal university of 2018, racism remains indelibly imprinted on the covert and sometimes blatant frameworks, theories and structures of our pedagogies and curricula. The racism is now exacerbated by class, and as always, intersecting with gender. The violence of nonrecognition, of separation from the self, has profound effects.

Black consciousness reminds us that disconnecting students from their cultural selves, separating the mind from the body and spirit, results in the annihilation of the self. Moodley goes on to argue that 'liberation was sought through a return to African values of communalism, shared decision-making, and more personal communication styles, in contrast to the individualism of white consumer' (Moodley 1991:238). These are the values that, if they are encouraged in our pedagogies and planning in foundation programmes and in mainstream university disciplines, will build capacity to make meaningful contributions to society. Although it has been critiqued for its sexist practices and the erasure of women in its articulations, a black consciousness lens can help us to understand the violences of oppression, even at universities, based on race. African feminism can orientate us towards the regeneration of the connection between mind, body and spirit, for the healing of staff and students.

African feminism reminds us of the African women whose histories and experiences have been marginalised and silenced. Masola argues that it matters that their names should not be forgotten. It matters that we find more writers from the past who were women. This will enrich us and our history, which has often shrunk the image of black women' (Masola 2018). Knowing the stories of the erased enriches the lives of all, and not just the individual. This is relevant for the thinking around foundation programmes because the success rates (Pather 2018) and potential to thrive in universities continues to show the same dire race, class and gender inequalities that characterise South Africa as the most unequal country in the world. Motsemme (2002; 2004) writes powerfully about how to piece together the fragments of beings that are worn down from constantly absorbing the violence of erasure and disconnection. Arguably, the students on the margins of success and failure in our institutions, including foundation programme students, including students 


\section{Corinne Knowles}

who are disadvantaged by mental health, financial, family, community, and linguistic burdens, are not being sufficiently nurtured or heard. The frameworks we use to define our pedagogies and programmes do not necessarily provide the means to break the silences, and the bonds of poverty and erasure, unless they include the voices of those who denied entry into the conversation about a better future for all. Motsemme (2002:649), speaking of women who endured apartheids' violences, cautions that,

Silence takes on meaning it was perhaps never intended for. It is transformed into a voice of defiance and self protection (1999). So speaking becomes both freeing and full of anxiety for black women. And in encouraging women to break silences, how do we ensure that patriarchal legacies are simultaneously undermined?

We are reminded that if our programmes and pedagogies are not undermining the unequal power relations that perpetuate inequality in our universities and society, they could increase the risk to those who are vulnerable. Thinking about foundation studies cannot be separated from the pedagogies that define the rest of the university - especially if the university is not addressing, powerfully and carefully, the race and class inequalities of society. We could use this lens to consider those students who fail to thrive academically or socially, who drop out for one reason or another at some stage of their degrees, who attempt suicide, who protest, or who quietly get their degrees without ever having been heard, or challenged, or transformed. We could do this differently, for instance if we used a pedagogy that recognised students, by using authors that speak to their realities, examples that are lifted from our local worlds, by engaging students in debates that did not shy away from uncomfortable topics and prejudices, by encouraging reflections that inspired self-learning. This would lead to the transformation of students who are stuck in poverty and racism, to students who are acutely aware of who they are and how they are located in the national transformation of inequality.

If we were to reconnect how students think, act and believe in how we think about foundation programmes, it would require us to do rigorous research that involved student perspectives in ways that recognised the structural inequalities that affect what they can think or say. It would mean that researchers negotiate power dynamics to relinquish our hold on the direction of research (Mkabela 2005). The research would aim to find empirical data 
through a framework that notices the structural challenges, listens for the silences, recognises how power is being facilitated. This kind of research recentres students to be part of the research process that affects them. It reconnects theory with the idea of a public good.

If we shift our thinking about students to see them as co-researchers in our theorising about foundation programmes, we have the opportunity to tap into the rich repository of experience that they bring with them to the university. We can anticipate that they will leave us with a sounder sense of themselves and an understanding of society and the contribution they can make. When students and their worlds become central in how we think about our curricula, readings, pedagogy and assessments, it implies that we are practicing the kind of democratic freedom imagined in the Freedom Charter (1955), which proposes that 'the aim of education shall be to teach the youth to love their people and their culture, to honour human brotherhood (sic), liberty and peace'. Centring the poor black student with a view to successful graduation leads to more than individual success, but also emphasises their (and our) obligation to building a better country for all. Speaking of universities, Baatjies urges that 'these institutions need to be protected as spaces which represent the values of a substantive democracy and sites of struggles for education as a public good' (Baatjies 2005: 1).

As academics who work in the field of foundation programmes, we can help to champion the cause of poor black students, so that they remain central to our thinking. Vally argues that 'Academics must lead the defence of higher education as a public good and an autonomous sphere of critical democratic citizenry, and resist commercial and corporate values to shape the purpose and mission of our institutions' (2007:25). He recommends that part of our work is to link the ideas and theories we teach to "community needs and struggles' that recognise the cultures and contexts of our students. Students are our connection to the community, and by recognising their realities, and by using thinkers and authors who write with them in mind, we open up a university education that is useful to the poor black student, as well as to society.

\section{Conclusion}

This paper has argued for a different set of theories to think about foundation studies - Critical Race Feminism, Black Consciousness, and African feminism. 


\section{Corinne Knowles}

The theories have been selected for the way that they place the object of our concern (the poor, black student) as a subject, central to the thinking around these programmes. These theories remind us of the need to reconnect the mind, body and spirit of our students when we devise programmes to support them, moving away from a more neoliberal approach which tends to see the student as an economically viable entity, and which orientates our pedagogies to see students as generic intellectual beings, rather than as whole people who are structured socially and politically.

The dilemma that we face in this sector in South African universities is this: while we might approach teaching and learning in the foundation programmes with a more holistic, student-centred approach, the university is becoming more neo-liberally orientated. The paper reminds us of the idea of the university as a public good. Situated as it is in a profoundly unequal society, the university's purpose as a public good is to stimulate and facilitate contributions that address the deeply etched class and race divides that shape our society in South Africa. How our students, and in particular, poor, black students, experience these social structures is relevant to the content and pedagogies of our teaching strategies in universities and in foundation programmes. The paper argues that the theories we use to think about foundation studies must recognise and include those who are least advantaged in society and the university system, so that they are equipped and inspired to contribute meaningfully to the necessary transformations in our country. The theories look at foundation studies as an integral part of the university as a whole, in that if both are not aligned to a political project of social justice and transformation, the foundation studies will set students up for failure. If, however, we re-orientate our theories about the university, by re-centring the poor black student, we make their relevant contributions to South African society a very real possibility. This is the kind of 'success' that is contemplated in this paper - not a narrow individual benefit, but a shift in how foundation studies, graduates and universities can help to shape the transformations of race and class inequality in South African society.

\section{References}

Appiah, K.A. 2006. Cosmopolitanism: Ethics in a World of Strangers. Penguin: London 
Baatjes, I.G. 2005. Neoliberal Fatalism and the Corporatisation of Higher Education in South Africa. Quarterly Review of Education \& Training in South Africa 12,1: 25 - 33.

Badat, S. 2001. Re-Inserting the 'Public Good' into Higher Education Transformation: Introduction. KAGISANO Higher Education Discussion

Series: Re-inserting the 'Public Good' into Higher Education 1: 4 - 8.

Badat, S. 2011. Scholarship in a Context of Transformation. Lecture, Academic Orientation Programme, Rhodes University.

Berry, T.R. 2010. Engaged Pedagogy and Critical Race Feminism. Educational Foundations 24: 19 - 26.

Biko, S. 1978. Black Consciousness and the Quest for a True Humanity. Ufahamu: A Journal of African Studies 8,3.

Boughey, C. 2010. Rhodes University Extended Studies Review Report. Available at:

https://www.ru.ac.za/media/rhodesuniversity/content/institutionalplannin g/documents/Self\%20evaluation\%20report\%20ESU\%20final\%20draft\% 20April\%2009.pdf

Centwa, S. 2013. Tales of a Divided City: Not a Place for Peasants. Grocotts Mail. http://grocotts.pl-dev.co.za/2014/03/10/tales-of-a-divided-city-nota-place-for-peasants/ (Accessed June 2018.)

CHE Report of the Task Team on Undergraduate Curriculum Structure 2013. A Proposal for Undergraduate Curriculum Reform in South Africa: The Case for a Flexible Curriculum Structure. Pretoria: CHE. Available at: https://www.che.ac.za/sites/default/files/publications/Full_Report.pdf

Chengeta, G. 2018. '\#RUReferenceList: The Fear of Repercussions still Lingers.' Mail and Guardian. Available at: https://mg.co.za/article/201807-06-00-rureferencelist-the-fear-of-repercussions-still-lingers (Accessed June 2018.)

Childers-McKee, C.D. \& K. Hytten 2015. Critical Race Feminism and the Complex Challenges of Educational Reform. Urban Rev 47:393 - 412. https://doi.org/10.1007/s11256-015-0323-Z

Daniels, P. 2015. Rhodes University's Black Student Movement Responds to Jonathan Jansen. The Daily Maverick. Available at:

https://www.dailymaverick.co.za/opinionista/2015-03-29-rhodesuniversitys-black-student-movement-responds-to-jonathanjansen/\#.WyEu40iFPIX

(Accessed June 2018.) 
Ellis, C.M. 2002. Examining the Pitfalls Faced by African American Males. In Jones, L. (ed.): Making it on Broken Promises: African American Male Scholars Confront the Culture of Higher Education. Virginia: Stylis Publishing.

Erskog, M. 2015. Transformation in Action. Daily Dispatch. Available at: https://www.dispatchlive.co.za/news/opinion/2015-04-14-

transformation-in-action/ (Accessed June 2018.)

Few, A.L. 2007. Integrating Black Consciousness and Critical Race Feminism into Family Studies Research. Journal of Family Issues 28,4.

https://doi.org/10.1177/0192513X06297330

Freedom Charter 1955. South Africa. Available at:

http://scnc.ukzn.ac.za/doc/HIST/freedomchart/freedomch.html

(Accessed October 2018.)

hooks, b. 1994. Teaching to Transgress. Education as the Practice of Freedom.

London: Routledge. https://doi.org/10.3366/para.1994.17.3.270

Jones, L. (ed.). 2002. Making It on Broken Promises: African American Male

Scholars Confront the Culture of Higher Education. Virginia: Stylus

Publishing, LLC.

Knowles, C. 2014. Vulnerability: Self-study's Contribution to Social Justice Education. Perspectives in Education 32,2: 89 - 101.

Linden, A. 2017. Unemployed Graduates in 'flash mob' Protests. Dispatch online. Available at: https://www.dispatchlive.co.za/news/2017-02-23unemployed-graduates-in-flash-mobprotests/?fbclid=IwAR34EQzzyFbnMi3DdkDYAFbrLB25Z6d2hFOQS PokJwfJG7WV4e_DjwvbpOo (Accessed October 2018.)

Mama, A. 2003. Restore, Reform but do not Transform: The Gender Politics of Higher Education in Africa. Journal of Higher Education in Africa 1,1: $101-125$.

Mahlangu, B. 2012. Interviewing Bantu Biko - Extracts from his Quotes. News24. Available at:

https://www.news24.com/MyNews24/Interviewing-Bantu-BikoExtracts-from-his-Quotes-20120912 (Accessed January 2019.)

Masola, A. 2018. Women who Wrote Themselves into History. Nal'ibali. Available at; https://nalibali.org/women-who-wrote-themselves-intohistory\# (Accessed June 2018.)

Mkabela, Q. 2005. Using the Afrocentric Method in Researching Indigenous African Culture. The Qualitative Report 10,1: 178 - 189. Available at: 
http://www.nova.edu/ssss/QR/QR10-1/mkabela.pdf

Mkhize, N. 2015. Tenacious Belief in the Ideal of the University. Business

Day. Available at:

https://www.businesslive.co.za/bd/opinion/columnists/2015-05-05-

tenacious-belief-in-the-ideal-of-the-university/

(Accessed June 2018)

Moodley, K. 1991. The Continued Impact of Black Consciousness in South Africa. The Journal of Modern African Studies 29,2: 237 - 251.

https://doi.org/10.1017/S0022278X00002731

Motsemme, N. 2017 in Wils, L. 2017. Gender, Sexuality and Transformation in Higher Education. Mail and Guardian Special Report. Available at: https://mg.co.za/article/2017-09-29-00-gender-sexualithy-and-

transformation-in-higher-education

(Accessed October 2018.)

Motsemme, N. 2002. Gendered Experiences of Blackness in PostApartheid. Social Identities 8,4: 647 - 673.

https://doi.org/10.1080/1350463022000068406

Motsemme, N. 2004. The Mute always Speak: On Women's Silences at the Truth and Reconciliation Commission. Current Sociology 52,5: 909 932. https://doi.org/10.1177/0011392104045377

Muller, S.M. 2018. The University is not a Factory. Mail \& Guardian.

Available at:

https://mg.co.za/article/2018-10-12-00-the-university-is-not-afactory/?fbclid=IwAR0zqL1Ht9-

3mI52MLF4kIHiud8A3D9zBoEpLK6a4pvkjHG_C7BSmrHYJI

(Accessed 23 November 2018.)

Muzenda, M. 2018. South Africa: Why has Rhodes University Silenced

Student Activism? This is Africa. Available at:

https://thisisafrica.me/rhodes-university-silenced-student-activism/

(Accessed June 2018.)

Ngugi wa Thiong'o [1986] 1998. Decolonising the Mind. In Rivken, J. \& M.

Ryan (eds.): Literary Theory: An Anthology. UK: Blackwell.

https://doi.org/10.1177/039219219804618409

Nguyen, D.J. \& J.B. Larson 2015. Don't Forget about the Body: Exploring the

Curricular Possibilities of Embodied Pedagogy. Innovative Higher Education 40,4: 331 - 344.

https://doi.org/10.1007/s10755-015-9319-6 
Ntseane, P.G. 2011. Culturally Sensitive Transformational Learning: Incorporating an Afrocentric Paradigm and African Feminism. Adult Education Quarterly 61,4. https://doi.org/10.1177/0741713610389781

Oloka-Onyango, J.J. \& S. Tamale 1995. The Personal is Political, or Why

Women's Rights are indeed Human Rights: An African Perspective on

International Feminism. Human Rights Quarterly 17,4: 691 - 731.

https://doi.org/10.1353/hrq.1995.0037

Pather, S. 2018. South Africa: The High Drop Out Rate of First-year University

Students. Inside Education. Available at:

https://www.insideeducation.org/featured/south-africa-high-drop-rate-

first-year-university-students/

(Accessed November 2018.)

Reddy, T. 2004. Higher Education and Social Transformation: South Africa

Case Study. Available at: http://open.uct.ac.za/handle/11427/22067

(Accessed January 2019.)

Salo, E. \& A. Mama 2001. Talking about Feminism in Africa. In Agenda, African Feminisms I, 50: 58 - 63.

Sayed, Y. 2008. Education and Poverty Reduction/ Eradication: Omissions,

Fashions and Promises. In Maile. S. (ed.): Education and Poverty

Reduction Strategies. Pretoria: HSRC Press.

Sesant, S., A. Eliseev \& S. Grootes 2015. 30 Students Arrested during \#FEESMUSTFALL Protests. Eye Witness News. Available at: https://ewn.co.za/2015/10/22/Fee-Must-Fall-campaign-sees-30-studentsarrested (Accessed November 2018.)

Singh, M. 2001. Re-Inserting the 'Public Good' into Higher Education Transformation. KAGISANO Higher Education Discussion Series: Reinserting the 'Public Good' into Higher Education Issue 1: 8 - 19.

https://doi.org/10.18820/9781928357056/01

Skade, T. 2016. Black Graduates, Mainly Women, at Highest Risk of Unemployment. Destiny Man. Available at:

https://destinyman.com/2016/04/05/women-and-black-graduates-facehighest-unemployment-

risk/?fbclid=IwAR0scvniGRwEeZXpZPSC6GwnRtVgKq5Dhdv7U4E7

5Ba0Cub7cXLmbpgEvzE (Accessed 20 November 2018.)

Statista 2018. Available at: https://www.statista.com/statistics/813010/youthunemployment-rate-in-south-africa/

(Accessed 20 November 2018.) 
Critical Race Feminist, $B C$, and African Feminist Perspectives

Vally, S. 2007. Higher Education in South Africa: Market Mill or Public Good? JHEA/RESA §, 1: 17 - 28.

White Paper for Post-School Education and Training 2013. Department of Higher Education and Training, South Africa. Available at:

http://www.dhet.gov.za/SiteAssets/Latest\%20News/White\%20paper\%2 0for\%20post-school\%20education\%20and\%20training.pdf

Corinne Knowles Humanities Extended Studies Rhodes University c.knowles@ru.ac.za 